\title{
De arabiske stater er kommet for at blive
}

\section{Af Peter Seeberg}

Det arabiske forår, som tog sin begyndelse i Tunesien i december 2010, syntes at have nærmest revolutionær karakter. Ikke bare bragte demonstrationer og opstande i løbet af få måneder tilsyneladende urørlige diktatorer i Tunesien og Egypten til fald, men i takt med at oprøret bredte sig til andre stater og nogle steder udviklede sig til væbnede konflikter og borgerkrig, forekom det relevant at stille spørgsmålet, om selve det arabiske statssystem - skabt i forbindelse med Osmannerrigets sammenbrud og afslutningen af Første Verdenskrig - var under forandring.

Diskussioner om hvad der er blevet benævnt Mellemøstens kunstige grænser og/ eller stater, som i næsten et helt århundrede har været et centralt tema i mellemøstforskningen, dukkede igen op til overfladen. Var der en sammenhæng mellem de særlige forhold, under hvilke de moderne mellemøstlige stater blev skabt, og de arabiske opstande? Og i videre forstand: ville de voldsomme konflikter i lande som Bahrain, Egypten, Libyen, Irak, Yemen og i særdeleshed borgerkrigen i Syrien føre til ændringer af Mellemøstens grænser og måske endda til nye statsdannelser?

Der er god grund til at modificere alt for forenklede forestillinger om den kunstige karakter af de arabiske grænser og stater og synspunktet om, at de mange problemer i den arabiske verden skyldes gennemførelsen af den hemmelige Sykes-Picot-aftale, der blev indgået i 1916, og som i mellemkrigstiden dannede baggrund for mandatstyret i Irak, Jordan, Libanon, Palæstina og Syrien. For det første opstod de nye staters grænser ikke ud af den blå luft, men var delvist baseret på historiske transformationsprocesser, der fandt sted i de arabiske territorier før det 20. århundrede. For det andet befandt nogle af de arabiske stater sig uden for Sykes-Picot-aftalens rækkevidde. Det var fx tilfældet for Yemen og Libyens vedkommende, begge aktuelt karakteriseret ved intern politisk splittelse.

For det tredje kan det i høj grad diskuteres, om det giver mening at tale om kunstige grænser og stater i Mellemøsten skabt som produkt af udefrakommende stormagters diktat efter krigens afslutning. De arabiske stater er resultatet af konflikter og krige, hvor også lokale aktører har spillet en central rolle, som det fx er til-

Peter Seeberg er ph.d. og lektor ved Syddansk Universitet. Hans primære forskningsområde er EU og Mellemøsten: Udviklingen i relationerne mellem EU og Mellemøsten med særlig henblik på det euro-mediterrane samarbejde og EU som aktør. 


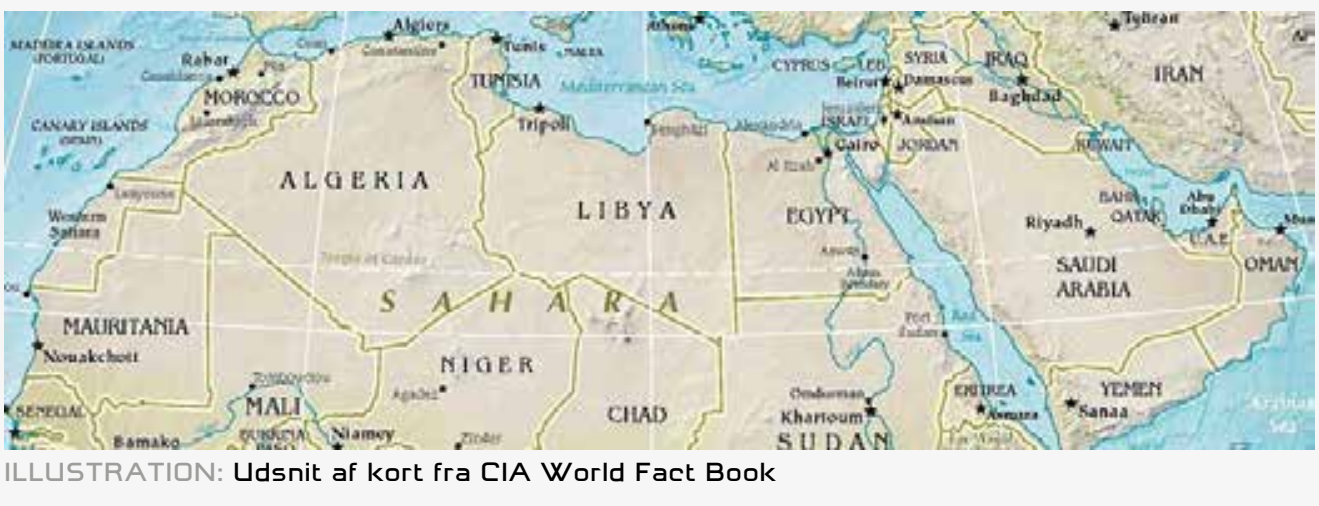

Maghreb og Mellemøsten

fældet med Egypten i første halvdel af det 19. århundrede. Landet var ikke bare reelt uafhængigt af Osmannerriget, men var endda i stand til at true dets dominans i Levanten. Disse realiteter ufortalt er myten om de kunstige stater og grænser dog særdeles livskraftig, ikke mindst i Mellemøsten, hvor en væsentlig del af kritikken af den vestlige indflydelse i regionen netop er bundet op på denne forestilling.

\section{Intakte mellemøstlige stater?}

En række mellemøstkendere konkluderer i tidsskriftet International Affairs (Nr. 93, 2017: 'Contentious borders: the Middle East and North Africa post-2011'), at uanset de senere års uro og ustabilitet er det sandsynligt, at de mellemøstlige stater og grænser vil forblive intakte. Ikke desto mindre er der i løbet af de senere år opstået lokale politiske magtcentre, som kan udvikle sig til egentlige stater eller få eksisterende stater til at udvikle sig til fejlslagne stater. Sådanne tendenser kan ses i fx Irakisk Kurdistan i det nordlige Irak, den såkaldte Rojava-region i det nordlige Syrien og i politisk splittede Libyen og Yemen.

Uanset om de lokale enheder forbliver en del af de eksisterende statsdannelser, eller om enkeltstater for en tid befinder sig i en tilstand af indre opløsning, udfordrer dette selvsagt de siddende regeringer og de nuværende grænser. Disse har stort set ikke ændret sig, siden de blev etableret i forlængelse af Første Verdenskrigs afslutning, og udråbelsen af Islamisk Stat (IS) i juni 2014 i de områder af Irak og Syrien, som bevægelsen kontrollerede, kan tilsyneladende ikke fastholdes. IS' succes som statsbygger synes afgørende på retur, men det ændrer ikke ved, at krisen i Syrien fortsat bidrager til at skabe ustabilitet $i$ særdeleshed i Levant-regionen, hvor meget store flygtningestrømme fører til sociale og politiske modsætninger.

Flygtningekrisen har udviklet sig til et af de senere års mest markante politiske fænomener med vidtrækkende konsekvenser for forholdet mellem Europa og Mellemøsten. Aftalen af marts 2016 mellem Tyrkiet og EU har sat en stopper for flygtningestrømmen i Det Ægæiske Hav, men i lande som Jordan, Libanon og Tyrkiet giver flygtningene anledning til lokale konflikter mellem disse og landenes befolkninger. I et videre perspektiv har flygtningespørgsmålet betragtelige sikkerhedsmæssige konsekvenser, som medvirker til at fastholde og udbygge autoritære træk ved staterne. Potentielt kan en fort- 
sat voksende tilstedeværelse af meget store antal flygtninge have destabiliserende konsekvenser for de mest berørte stater.

De mellemøstlige stater har altid været kendetegnet ved et fravær af indbyrdes samarbejde og dårligt fungerende mellemstatslige relationer. Dette skyldes ikke bare en ineffektiv Arabisk Liga, staternes autoritære karakter, fraværet af demokrati og et lavt niveau af politisk legitimitet. Problemerne skyldes også kolossale indkomstforskelle mellem staterne, betydelig økonomisk ulighed internt i de enkelte lande, mangel på økonomisk komplementaritet, der vanskeliggør samhandel i regionen, og store bureaukratiske, ofte korrupte offentlige institutioner. Endelig har interne væbnede konflikter og i nogle tilfælde krige staterne imellem (som $\mathrm{fx}$ Kuwaitkrigen i 1990-91, hvor Irak besatte Kuwait) polariseret den arabiske verden.

\section{De mellemøstlige stater har altid været kendetegnet ved et fravær af indbyrdes samarbejde og dårligt fungerende mellemstatslige relationer. Dette skyldes ikke bare en ineffektiv Arabisk Liga, staternes autoritære karakter, fraværet af demokratiog et lavt niveau af politisk legitimitet.}

Disse forhold har i udgangspunktet haft konsekvenser for, hvordan de enkelte stater har tacklet udfordringerne relateret til det arabiske forår. De senere års ustabilitet i Mellemøsten har svækket staterne, og det forekommer sandsynligt, at netop staternes forskellighed vil komme til udtryk i forbindelse med kommende kriser. I nogle tilfælde vil der være tale om indre opløsningstendenser, i andre økonomi- ske sammenbrud, i andre igen vil ændrede regionale alliancer have betydning for staternes evne til at klare sig. Denne artikel har til formål at præsentere en oversigt over tiden efter det arabiske forår og diskutere, om de aktuelt mest belastede stater i Mellemøsten i al deres skrøbelighed er i stand til at fastholde status som nationalstater med de eksisterende grænser.

\section{Permanent syrisk krise}

Protester og demonstrationer i Syrien i det tidlige forår $2011 \mathrm{blev}$ mødt med en selv for den syriske stats standarder voldsom brutalitet. Konflikten eskalerede til en omfattende militær konfrontation, hvor Bashar al-Assads styre kæmpede mod sin egen befolkning, der var organiseret i lokale militser og modstandsgrupper. Internationale ledere fordømte regimets adfærd over for det syriske folk og lod forstå, at man gjorde al-Assad ansvarlig for optrapningen af den syriske borgerkrig - og at den syriske leder måtte betragtes som siddende på lånt tid i $\mathrm{Da}$ maskus. EU-landene krævede første gang al-Assads tilbagetræden i august 2011, og i januar 2013 påpegede den europæiske udenrigspolitiske chef, Catherine Ashton, 'Assads fuldstændige tab af legitimitet i den syriske befolknings øjne', og at hans afgang var nødvendig.

De syriske grænser blev trukket efter Første Verdenskrig og er siden blevet justeret en enkelt gang, nemlig da den franske mandatmagt i 1939 forærede Hatay-provinsen i det nordvestlige Syrien til Tyrkiet. Officielle syriske landkort viser fremdeles provinsen som en del af Syrien. Der har imidlertid ikke siden været tegn på (eller krav om) ændringer af den syriske grænsedragning. I de første år efter 2011 anfægtede oprøret mod regimet ikke Syriens enhed som stat, men gradvist 
udviklede den syriske krise tegn på indre opløsning, først og fremmest ved de omfattende kampe over det meste af landet. Dertil kom dramatisk voksende flygtningestrømme, hvor især nabolandene Jordan, Libanon og Tyrkiet holdt for som modtagerlande. Samlet havde UNHCR i august 2017 registreret 5.165 .317 syriske flygtninge i lande uden for Syrien, men internt i Syrien var et endnu større antal personer fordrevet fra deres hjem - med over 6,5 mio. mennesker det største antal internt fordrevne i noget land i verden.

Selvom al-Assad i juni 2016 i det syriske parlament erklærede, at han ville 'befri hver eneste tomme af vort territorium, er dette mere end et år senere langt fra opnået. Syrien er således de facto ikke i besiddelse af hele statens territorium. Islamisk Stat kontrollerer fortsat dele af det østlige Syrien, om end kalifatet er under stærkt pres. Jabhat Fatah al-Sham og en lang række anti-Assad-grupperinger dominerer i andre dele af Syrien. I det nordlige og nordøstlige Syrien har kurdiske styrker magten i betydelige områder. Kurdiske grupperinger har anvendt betegnelsen Rojava (det vestlige Kurdistan) om det landområde, de dominerer. Ifølge geograf og Syrien-kender Leila Vignal har de imidlertid fra marts 2016 besluttet at anvende betegnelsen Nordsyrien om dette. Vignals vurdering er, at situationen i Syrien på kort og mellemlangt sigt repræsenterer en kaotisk situation kendetegnet ved permanent militær konflikt snarere end foregribelsen af nye politiske enheder,

Den siddende regering i Damaskus har siden 2011 overlevet mere end seks års krise og borgerkrig, intern og ekstern fordrivelse af mere end halvdelen af den syriske befolkning og langvarig etablering af enklaver og magtcentre i dele af Syrien. Det syriske Bảathparti er meget langt fra tid- ligere tiders styrke og fremstår på ingen måde som fremtidens magtbase for den syriske stat. IS er ikke slået, men repræsenterer næppe længere en trussel for den syriske stat. IS har ikke formået at skaffe sig folkelig opbakning til kalifatet, og dette har uden tvivl bidraget til det nederlag, der synes på vej. Det kurdiske projekt i det nordlige Syrien mangler ikke lokal legitimitet, men det har vanskelige odds at slås imod i form af tyrkisk modstand og mangel på regional og international anerkendelse.

En forsigtig sammenfatning peger derfor i retning af en fortsat eksistens af en (omend i markant grad svækket) syrisk stat, formentlig med et delvist regionaliseret politisk system.

\section{Libanon - overlevelse på trods}

En så dyb og langvarig krise som den syriske har naturligvis haft stor indflydelse på nabolandene, i særdeleshed Libanon og Jordan. I modsætning til de fleste andre arabiske stater var det libanesiske styre stort set ikke udsat for et folkeligt pres i forbindelse med det arabiske forår.

Det konfessionelt baserede politiske system har ikke en autokratisk diktator i spidsen, men en kompleks politisk ledelse, der repræsenterer de væsentligste etnisk-religiøse mindretal. Systemets mest iøjnefaldende uretfærdighed er, at den shiamuslimske befolkningsgruppe ifølge forfatningen er tildelt 22,5 pct. af mandaterne i parlamentet, mens gruppens andel af den libanesiske befolkning er vokset til formentlig 40 pct. Politisk rummer disse 40 pct. bl.a. Amal-bevægelsen og magtfulde Hizbollah, der er dominerende i Libanon via sin politiske, militære og mediemæssige slagkraft.

Hizbollah har, stærkt støttet af Iran, taget aktivt del i krigen i Syrien på regimets side, hvilket selvsagt er stærkt kontrover- 
sielt i Libanon. Landet er desuden præget af at have modtaget over en million syriske flygtninge, som i betydelig grad har belastet den libanesiske stat.

Staten har fulgt en erklæret non-encampment politik, og det er interessant, at et flertal af flygtningene, som vist af den engelske migrationsforsker Lewis Turner, er i beskæftigelse. Arbejdet foregår typisk inden for det ufaglærte område - som i 1990'ernes Libanon, hvor syriske migrantarbejdere påtog sig det meste af det hårde og beskidte arbejde i forbindelse med rekonstruktionen af Beirut efter borgerkrigen.

\section{Selvom det kan forekomme nærmest ubegribeligt, har Libanon været i stand til at overleve krige og kriser $i$ landet, en overvældende politisk dominans fra syrisk side og senest en dyb politisk krise, hvor landet i lang tid var uden såvel præsident som fungerende regering.}

Mellemøstkender og nationalismeforsker Theodor Hanf har i flere undersøgelser af libanesernes holdninger til deres nation, både under og efter borgerkrigen, påvist en stærk identifikation med Libanon på trods af etnisk-religiøse skel, sociale forskelle mv.

Selvom det kan forekomme nærmest ubegribeligt, har Libanon været i stand til at overleve krige og kriser i landet, en overvældende politisk dominans fra syrisk side og senest en dyb politisk krise, hvor landet i lang tid var uden såvel præsident som fungerende regering. Den politiske krise er (for en tid) overstået, men situationen i Libanon forekommer langt fra stabil. Dette synes imidlertid at være et kronisk vilkår for den libanesiske stat, hvis status som en af Mellemøstens nationalstater næppe for alvor er anfægtet af den regionale uro.

\section{Pragmatisk støtte til kong Abdullah} En lignende konklusion er relevant $\mathrm{i}$ Jordans tilfælde, men på helt andre betingelser.

I modsætning til Libanon var Jordan berørt af det arabiske forår. Allerede før oprørene i Tunesien og Egypten var der protestdemonstrationer i flere jordanske byer efter parlamentsvalget den 9. november 2010. Protesterne skyldtes, at valget på baggrund af stærkt favoriserende valglove endnu engang havde resulteret $i$ en regimeloyal majoritet.

Den jordanske befolkning var derfor meget optaget af det arabiske forår, og i 2011-12 var der forholdsvis mange, omend oftest mindre og overvejende fredelige, demonstrationer i Jordan. Desuden foregik en helt utypisk kritisk offentlig diskussion, som da den kendte jordanske politolog Hassan Barari ved et offentligt arrangement i Amman i december 2012 hævdede, at kongen udskiftede sine regeringer, som han skiftede underbukser, og forudså stigende kritik af regimet.

Det var udviklingen i Syrien, der gradvist vendte billedet. Intensiveringen af de væbnede kampe mellem den syriske opposition og al-Assads hær og det voksende antal syriske flygtninge, der passerede grænsen til Jordan, gjorde jordanerne nervøse og fik dem til pragmatisk at moderere kritikken af kongedømmet. Og med IS' bestialske henrettelse ved levende afbrænding af den jordanske pilot $\mathrm{Mu}$ ath Safi Yousef Al-Kasasbeh i januar 2015 fulgte yderligere opbakning til kong Abdullahs styre.

Kongen har over for internationale donorer med held forsøgt at slå sig op som fredens fortaler i en urolig region, og med 
deltagelse i anti-IS koalitionen og modtagelsen af omkring 1,5 million syrere (heraf 660.000 UNHCR-registrerede flygtninge) er forsøget lykkedes. London-konferencen i februar 2016, hvor løfter fra bl.a. EU og Verdensbanken om betydelig økonomisk støtte blev givet, lancerede også en interessant ny plan (Jordan Compact), der skulle resultere i øget beskæftigelse blandt arbejdsløse jordanere, men også af et stort antal syriske flygtninge i Jordan - og føre til øget samhandel med EU-landene, bl.a. gennem lempelse af reglerne for jordansk eksport.

Jordan har været god til at udnytte den ustabile situation i regionen til egen fordel. Den jordanske stat har desuden en af Mellemøstens mest velfungerende efterretningstjenester at støtte sig til, som arbejder tæt sammen med Mossad, CIA og andre landes sikkerhedstjenester. Det handler både om at forhindre spredningen af radikal jihadisme i regionen, men også i Jordan internt. Ydermere er arbejdet knyttet til de syriske flygtninge også med til at sikre tætte alliancer til regionale aktører herunder GCC-staterne, som har inviteret Jordan med i GCC, og til internationale aktører, i særdeleshed USA og EU, for hvem Jordan fremstår som et stabilt og loyalt regime, som det gælder om at sikre overlevelse i et kaotisk Mellemøsten.

\section{Egypten under permanent pres}

Af indlysende demografiske og geostrategiske årsager er Egypten en væsentlig aktør både i den arabiske verden og på den internationale scene. Egyptens hovedstad Cairo er hjemsted for Den Arabiske Liga og var under Nasser et centrum for arabisk nationalisme.

Statens grænser ændrede sig i forbindelse med juni-krigen mod Israel i 1967, men med Camp David-aftalen af 1979 fik
Egypten Sinai tilbage. Egyptens revolution i januar 2011 står som et af det arabiske forårs mest signifikante momenter, men også som et monument over en udvikling, som ikke var i stand til at bære igennem. Egypten har siden Mubaraks fald i februar 2011 gennemlevet en dramatisk periode, hvor et demokratisk valgt, men fejlslagent regeringsprojekt baseret på Det Muslimske Broderskab (MB) for en tid udfordrede den væsentligste magtbase i landet, det egyptiske militær.

Det var formentlig militærets hensigt at tillade en demokratisk proces at udfolde sig og i forlængelse af valget af Muhammad Morsi som præsident og indsættelsen af en regering domineret af $\mathrm{MB}$ at lade Egypten gennemgå en udvikling, hvor en magtdeling lod militæret styre bag kulisserne. Strategien slog fejl, i høj grad fordi MB-regeringen viste sig inkompetent. Voksende økonomiske problemer og stigende afhængighed af internationale donorer og långivere skabte en usikker og ustabil situation politisk såvel som økonomisk. Det var afgørende for militæret både at sikre sin politiske autonomi og sine erhvervsinteresser, og derfor var landets stabilitet afgørende. Med en elegant formulering af den tyske Egypten-ekspert Stephan Roll indså militæret, at en stat $\mathrm{i}$ staten ikke kan eksistere, hvis der ikke er en stat.

Derfor gennemførte militæret i juli 2013 et kup mod regeringen og Morsi, og i forlængelse heraf blev der indsat et militærstyre, som siden har haft magten i Egypten. Regimet er anført af Abdel-Fattah el-Sisi, forsvarsminister under Morsi og siden kuppet ubestridt leder af militærstyret. I marts 2014 trak al-Sisi sig fra sine militære poster, og i maj blev han med 97 pct. af stemmerne valgt som Egyptens præsident i spidsen for et brutalt regime, 
der i de efterfølgende år har undertrykt enhver opposition.

Styret har dog ikke været i stand til at løse Egyptens problemer. Økonomien er svag, bl.a. fordi turismen svigter. Aftaler med IMF om reformer skaber fortsat $ø$ konomiske trængsler for Egyptens fattige befolkningsgrupper, og devalueringer og nedskæringer bidrager yderligere hertil. Den egyptiske stat står således over for potentielle trusler i form af social uro og radikalisering.

\section{Irak og Irakisk Kurdistan?}

I modsætning til Egypten oplevede Irak kun i begrænset omfang et arabisk forår. Mens demonstrationer og oprør fandt sted i Egypten og Tunesien i de første måneder af 2011, befandt Irak sig midt i en vanskelig proces, som bl.a. handlede om den amerikanske tilbagetrækning af tropper fra det etnisk opsplittede land.

Et rodet forløb endte med, at de sidste militære enheder forlod Irak i december 2011, i bagklogskabens lys formentlig for tidligt. Det var imidlertid ikke indlysende i 2011, hvor sikkerhedssituationen i Irak forekom acceptabel og olieproduktionen nogenlunde stabil - og det er næppe heller givet, at en mindre amerikansk tilstedeværelse ville have forhindret IS' senere militære fremskridt. Den nuværende regering under Haider Al-Abadi er under stærkt internt pres, mest markant da parlaments- og regeringsbygninger i april 2016 blev angrebet af den shiamuslimske Mahdi-milits.

I sommeren 2014 blev det anslået, at IS var ansvarlig for mere end 75 pct. af alle terrorangreb i Irak. Bevægelsen erobrede storbyen Mosul, Tikrit og dele af Anbar, Nineveh, Kirkuk, Salah al-Din og Diyala-provinserne - samlet op mod en tredjedel af Iraks territorium. Modan- greb blev sat ind allerede fra marts 2015, men det tog mere end tre år, før hovedbyen Mosul i juli 2017 igen var tilbage på regeringshænder, og truslerne fra IS mod Iraks territorium var afværget. Forsøg på at destabilisere det irakiske regime ved terrorangreb og gengældelsesaktioner forekommer fortsat fra IS' side, der med positioner vest og syd for Mosul ikke er definitivt slået.

Irak- og Kurdistanekspert Johannes Jüde gør i en analyse af situationen i Irakisk Kurdistan gældende, at den nordirakiske region er i besiddelse af de ifølge Montevideo-konventionen nødvendige kendetegn ved en stat: en permanent befolkning, et afgrænset territorium, en regering og evnen til at indgå forbindelser med andre stater. I ly af en no-fly zone etableret i 1991 har Irakisk Kurdistan udviklet sig til en på mange måder velfungerende region, som kan blive den næste stat i verden. Dette kræver imidlertid anerkendelse fra det internationale samfund, hvilket lige nu forekommer mindre sandsynligt.

De regionale magter er med undtagelse af Israel imod en kurdisk statsdannelse, idet Tyrkiet dog har så væsentlige interesser i samhandel (herunder olieimport), at man under pres måske ville overveje at ændre signaler. Sammenfattende er et samlet Irak dog langt fra en til evig tid given realitet. Tidligere tiders enhed baseret på rå undertrykkelse under Ba’ath-styret er historie, og den kurdiske region kan, med to årtiers velfungerende samarbejde mellem de to kurdiske partier PUK og KDP som statsbyggende faktor, være tæt på reel løsrivelse.

\section{Maghrebstaterne: top og bund}

Maghrebstaternes politiske og rettighedsmæssige formån blev af det ame- 
rikanske analyseinstitut Freedom House i 2017, med anvendelse af dets kendte skala fra 0 til 100, bedømt således: Algeriet og Marokko scorede med hhv. $35 \mathrm{og}$ 41 forholdsvis lavt, mens Libyen med 17 var nær den absolutte bund. Bedømmelsen af Tunesien lå på et helt andet niveau, 78 (til sammenligning en anelse over Ungarns score på 76). Siden Zine El Abidine Ben Ali 14. januar 2011 i hast forlod Tunesien, har landet udviklet sig til en relativt velfungerende demokratisk stat, som dog er under pres indefra. For det første er sikkerhedssituationen i landet problematisk. Især i 2015 blev Tunesien ramt af flere terrorangreb rettet mod både turister og regeringsstyrker med samlet over 70 dræbte, men også 2016 og 17 har set mindre angreb og forsøg på angreb, som blev standset i tide. Op mod 3.000 tunesere kæmper eller har kæmpet for IS, en del af dem er vendt hjem og udgør en alvorlig sikkerhedstrussel.

Valgene i 2011 og 2014 har været velgennemførte og regeringsskiftet fra det moderat islamistiske al-Nahdah til det konservative, overvejende sekulære Nidaa Tounes foregik forholdsvis gnidningsfrit. Siden har især indre stridigheder i Nidaa Tounes skabt flere regeringskriser og politisk uro. Det er afgørende, at regeringen får gjort noget ved en svag økonomi med over 15 pct. arbejdsløshed, lav økonomisk vækst og levestandard og krise i turismesektoren. Støtten fra bl.a. EU er blevet forstærket de senere år og bidrager til Tunesiens stabilitet, som dog ikke skal overvurderes.

I et års tid efter Muammar Gaddafis fald i oktober 2011 var der i Libyen en vis moderat optimisme med hensyn til fremtiden, som også deltes af udenlandske iagttagere. Valget af en overgangsregering i juli 2012 blev positivt bedømt af uden- landske observatører og syntes at pege fremad mod yderligere politiske fremskridt, men allerede i løbet af 2012 blev det klart, at der havde udviklet sig en art dobbeltmagtssituation, hvor de valgte ledere blev udfordret af selvbestaltede militsledere. I de efterfølgende år var der voksende ustabilitet i landet, og ikke mindst hovedstaden, Tripoli, udviklede sig til en by, hvor sikkerhedssituationen var mere end usikker, og hvor udenlandske repræsentationer og organisationskontorer blev lukket ned.

Valget i juni 2014, der skulle lede frem mod etableringen af et egentligt parlament, viste lav valgdeltagelse (18 pct.), og efter valget gennemførte islamistiske militser et kup i Tripoli ved at udnævne sig selv til regering og fordrive den valgte regering, der tog ophold ved Tobruk i det østlige Libyen. Bestræbelser i FN-regi på at etablere en samlingsregering har endnu ikke vist varige resultater, og Libyen befinder sig aktuelt i en dyb politisk krise. Mens Tunesien således giver håb for demokratiets muligheder i Mellemøsten, udgør Libyen en noget nær katastrofe.

I modsætning til Tunesien og Libyen syntes Algeriet og Marokko i det væsentlige at styre uden om det arabiske forår. Mindre demonstrationer i Algeriet, bl.a. med fokus på boligmangel, blev mødt med usædvanlig tolerance fra den algeriske regerings side, og dette blev fulgt op af en række statslige initiativer, der skulle inddæmme mulige protester inspireret af begivenhederne i Tunesien og Egypten. Betragtelige lønstigninger for offentligt ansatte blev fulgt af forhøjelser af subsidier på basisfødevarer. Et forbud mod demonstrationer blev afskaffet, samtidig med at mediekampagner, der beskrev udviklingen i Libyen, herunder truslerne fra radikale bevægelser, kunne ses i det stats- 
kontrollerede tv. Flere iagttagere har endvidere gjort gældende, at der var en frygt $\mathrm{i}$ den algeriske befolkning for, at 1990'ernes tragiske borgerkrig i Algeriet skulle dukke op igen i nye iklædninger. Den algeriske stat synes aktuelt i gang med en vis moderat åbning mod resten af verden. Det dybt autoritære regime under ledelse $\mathrm{af} \mathrm{Ab}$ delaziz Bouteflika er ikke under alvorligt internt pres, og der er betydelige ressourcer til rådighed, som kan anvendes til om nødvendigt at købe sig til loyalitet i befolkningen.

En række demonstrationer fandt sted i nabostaten Marokko i det første halvår af 2011. Protesterne krævede en ny demokratisk grundlov, en ny regering og et opgør med udbredt korruption. I en tv-transmitteret tale til befolkningen i marts lovede Kong Mohammed reformer; løfter, som blev gentaget og udbygget i en ny tale i juli.

Kongen har godt hjulpet af en teknokratisk, men kompetent statsadministration været god til at levere, hvad han stillede i udsigt, og har bl.a. derfor formået at sikre sig en vis opbakning i befolkningen. Kritikere har dog hævdet, at reformpolitikken er blevet gennemført med en top-down tilgang snarere end via demokratiske processer. Marokko kan betegnes som et blødt autokrati, der har sikret sig mod en kritisk opposition ved at tillade forholdsvis liberale medier, et aktivt civilsamfund og lokal selvbestemmelse. Algeriet og Marokko står således, omend på vidt forskellige betingelser, som to relativt stabile nordafrikanske stater.

\section{Golfstaterne og Yemen}

Det arabiske forår fik vidt forskellige forløb i Den Arabiske Golf. Oliestaterne i GCC klarede sig igennem udfordringerne bl.a. ved som rige rentier-stater at udnytte deres muligheder for at lægge låg på protester og demonstrationer gennem økonomiske foranstaltninger, subsidier mv.

Endvidere blev befolkningen, som beskrevet bl.a. af Golf-forsker Kristian Coates Ulrichsen, udsat for et ideologisk bombardement, hvor det blev gjort gældende, at urolighederne var resultatet af iransk påvirkning. Derved blev den shiitiske opposition i Saudi-Arabien og Bahrain delvist udmanøvreret, og ved at karakterisere demonstranterne som illoyale og/eller ekstremister styret fra Teheran lykkedes det at undgå etableringen af en opposition på tværs af religiøse grupperinger i GCC-staterne.

Endelig blev der fra statens side orkestreret regeringsloyale demonstrationer som modvægt til protesterne, som i Bahrain havde betydeligt omfang, ligesom Saudi-Arabien valgte at intervenere direkte i Bahrain for at bidrage til at eliminere oppositionen. Som forholdene de følgende år udfoldede sig i Levanten, bidrog krisen i Syrien og fremvæksten af IS utvivlsomt også til indirekte at lægge en dæmper på Golf-befolkningernes protester.

Oman oplevede demonstrationer allerede umiddelbart efter, at Ben Ali havde forladt Tunesien, men sultanatet oplevede ikke optøjer, der eskalerede i vold - og slet ikke begivenheder, der anfægtede regimet eller staten.

I modsætning hertil var det fra starten af urolighederne i Yemen tydeligt, at der var tale om en revolte, der i høj grad lignede, hvad der fandt sted i Tunesien og Egypten. Konteksten var imidlertid meget anderledes: landet er ekstremt fattigt og etnisk opsplittet. En del af den nationale elite omkring præsident Ali Abdullah Saleh formåede som vist af Yemen-kender Elham Manea at holde sig ved magten 
gennem mere end to årtier ved at monopolisere støtten fra internationale aktører, som frygtede at staten skulle falde fra hinanden.

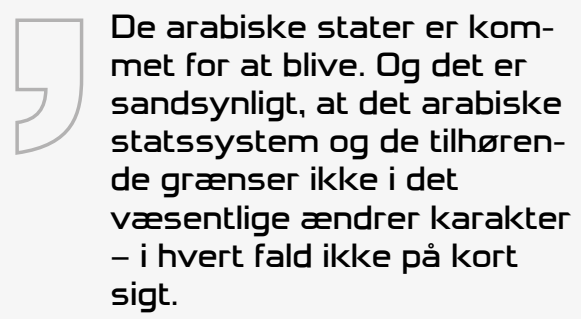

Men i længden gik det ikke, og i 2012 trådte Saleh tilbage. Konflikten i Yemen kan opfattes som en overvejende lokal affære, som aktuelt er endt med en alliance mellem Houthi-styrker og tidligere præsident Saleh, der tilsammen har magten i Sanaa - en alliance, der ikke spås lang levetid. Konflikten kan samtidig forstås som et udtryk for den regionale modsætning mellem Saudi-Arabien og Iran, førstnævnte støttet af en række arabiske stater, USA, England og Frankrig. Taberen er det yemenitiske folk, der lider under de mange års væbnede konflikt og desuden under sygdommen kolera, som har spredt sig i det ludfattige land. Sammenfattende må den yemenitiske stat betegnes som tæt på indre opløsning.

\section{Kommet for at blive}

De arabiske stater er kommet for at blive. Og det er sandsynligt, at det arabiske statssystem og de tilhørende grænser ikke i det væsentlige ændrer karakter - i hvert fald ikke på kort sigt.

Men man er nødt til at formulere sig med forsigtighed. En række lande i Mellemøsten er for tiden mere ustabile, end det længe har været tilfældet, og det arabi- ske forår og de autoritære regimers i nogle tilfælde særdeles voldelige svar på udfordringerne i den forbindelse bærer utvivlsomt en del af forklaringen på denne aktuelle misere. Den syriske krise synes nærmest at have fået permanent karakter, og dette er i sig selv blevet et centralt tema i de forholdsregler, der træffes regionalt og internationalt for at afbøde nogle af krisens konsekvenser.

Det etnisk baserede Rojava kan på sigt komme til at udgøre en delvist autonom region i et regionaliseret Syrien, men uanset en høj grad af lokal opbakning vil regionale og internationale aktører formentlig modvirke en udvikling frem mod nationalt selvstyre. Det forekommer usandsynligt, at stort set de samme aktører vedvarende vil være i stand til at forhindre etableringen af et selvstændigt Kurdistan i det nordlige Irak.

En gennem lang tid indædt modstander af projektet, Tyrkiet, har økonomiske motiver til at fastholde et godt forhold til den regionale kurdiske regering og kunne måske på den baggrund finde på at moderere sin traditionelle modvilje.

Libyen og Yemen udgør aktuelt to vidt forskellige - fejlslagne stater. Det taler imod indre opsplitning af de to stater, at der ikke står udtalte regionale interesser bag de iøjnefaldende problemer, selvom nord-syd modsætningen udgør en del af problemet i Yemen. Begge stater er i dyb krise. I Libyens tilfælde kan man håbe på et positivt scenario, hvor den $\mathrm{FN}$-initierede samlingsregering over tid opnår større politisk støtte i landet. I Yemen er det mere end svært at få øje på en farbar vej ud af krisen. 